\title{
Declarative Principles Registration Of Copyright Rights In Disruption Era
}

\author{
Andy Usmina Wijaya ${ }^{1}$, Rihantoro Bayu Aji ${ }^{2}$ \\ \{andyusmina@uwp.ac.id $\left.{ }^{1}\right\}$ \\ Wijaya Putra University, Indonesia
}

\begin{abstract}
In the era of globalization which regulates the issues of copyright globally. The development of information technology is increasingly becoming one of the causes of disruption. The era of disruption can bring changes to the principle of copyright ownership in Indonesia from constitutive principles to declarative principles. The declarative principle is the principle of copyright protection after it has been made, and is known, heard, seen by other parties. In other words, the principle of copyright ownership will get protection from the State since the first announcement. The era of disruption was born with the flourish of the digital era and internet networks, especially computer information technology. This study discusses the important role of copyright announcements in the era of disruption related to the principle of copyright ownership in Indonesia which adheres to the declarative principle. Announcements are readings, broadcasts, exhibitions, creations using any tool whether electronic or non-electronic or doing in any way so that a work can be read, heard or seen by others. With the existence of the internet network, the announcement as the most important thing in implementing the declarative principle of copyright registration will greatly help the creator in obtaining copyright protection from the state. Furthermore in this study also discusses the framework of protection and proof of copyright itself and the elaboration of the declarative principle that applies to copyright law in Indonesia.
\end{abstract}

Keywords: Declarative Principles, Disruption, Copyright

\section{Introduction}

At the beginning of the 21 st century is a sign of the beginning of rapid technological advances in the fields of digital, telecommunications, information and the economy. This has driven the flow of globalization in the industrial and trade fields and investment, which has made the world a single market together with an international agreement / convention signed by several countries in the world. This makes consequences for the countries that signed to submit and comply with these international provisions.

Indonesia is one of the countries participating in the association of the world community by becoming a member of the Agreement Establishing the World Trade Organization, including the Trade Related Aspects of Intellectual Property Rights Agreement (Agreement on the Aspects of Trade in Wealth Rights). Intellectual) was ratified through Law Number 7 of 1994. Indonesia also ratified the Berne Convention for Protection of Artistic and Literary Works through Presidential Decree Number 18 of 1997 and Agreement on the Establishment of the World Intellectual Property Organization (WIPO). Indonesia's subsequent participation in the 
global community is at the WIPO Copyright Treaty and the WIPO Phonograms and Performance Treaty.

In this era of globalization, all aspects of life quickly change. This rapid change and creating a world as if without boundaries is a feature of human life in an era of disruption. Progress that runs automatically both directly and indirectly has resulted in the existence of the law that regulates it. Because with rapid progress in the world community, including Indonesian society, it needs to be accompanied by a touch of law so that legal existence can be maintained.

With regard to the rapid development of science and technology at this time, the public demands that all aspects of the service run quickly including the copyright registration service so that the creator will immediately obtain copyright protection from the state. Indonesia recognizes and rewards copyrighted works through Law Number 28 of 2014 concerning Copyright, hereinafter referred to as UUHC. In particular, the UUHC also regulates the registration of works carried out by the applicant, both the creator and the rights holders.

With the establishment of a system of registration of creation, it is followed by the making of administrative implementation provisions from the stages of the registration process of creation to the issuance of the Certificate of Creation by the Directorate General of Intellectual Property Rights hereinafter referred to as the Director General of Intellectual Property Rights. The Registration Certificate of the Work is deemed to facilitate verification if there is a dispute regarding Copyright whether it is litigation in court or outside the court.

Based on the provisions of international conventions in the field of copyright, including the practice of protecting the creation of works of art and literature does not require the existence of registration of works in certain institutions in a country. This is in line with the doctrine used in the copyright regime in protecting and protecting copyright. A work has received legal protection since the creation was completed, and can be known, heard, seen by another party. This means that a creation is not in the form of ideas or ideas but is already a real expression of the idea or idea. So that the provisions of ownership of a work are not determined by the existence of registration or registration, but rather a copyrighted work has been protected since it was first announced. The doctrine or principle is known as the declarative principle.

For this reason, this study will discuss the principle of declarative copyright registration according to the UUHC and the application of declarative copyright registration principles in the era of disruption.

\section{Discussion}

\subsection{Declarative Principles of Copyright at UUHC}

The development of intellectual property rights law, hereinafter referred to as IPR, can now be stated that IPR legal politics carried out related to the implementation of the declarative principle on copyright registration is first, encouraging and utilizing the birth of science and technology by Indonesian citizens for national interests. Some of the activities carried out include encouraging the establishment of IPR centers in universities (PT) and Research and Development institutions ( $R \&$ D Institutions) that are expected to coordinate the registration of research results that have the potential for IPR, especially copyright and liaise with PT and R \& $\mathrm{D}$ institutions with the industry. In ASEAN countries or perhaps in the world, Indonesia has the most IPR centers, but in productivity in the IPR sector, Indonesian copyright in particular is lagging behind. One reason for Indonesia's lagging with other countries is the low budget[1]. 
Second, correcting copyright law and building a culture of copyright law. To implement this copyright law politics, several activities carried out by the Director General of IPR are collaborating with various parties both at home and abroad. Furthermore, implementing decentralization of receipt of copyright registration at the Regional Office of the Ministry of Law and Human Rights in the Capital of the Province, although only limited to the office of recipient of copyright application documents based on Decree of the Minister of Justice of the Republic of Indonesia Number: M.09-Pr.07.06 of 1999 concerning Office Appointment Territory of the Ministry of Justice To Receive Applications for Intellectual Property Rights, as amended by Decree of the Minister of Justice of the Republic of Indonesia Number: M.11.Pr.07.06 of 2003 concerning Appointment of Regional Offices of the Ministry of Justice to Receive Applications for Intellectual Property Rights. The next activity is to utilize internet information technology in accepting copyright registration. So far the legal culture has not been fully developed properly, although knowledge of copyright is increasing. Indicators that show this are, among others: the absence of an increase in copyright registration.

As a consequence of signing the TRIPs Agreement, Indonesia must standardize the implementation of the TRIPs Agreement, including:

1. Enforce the 1971 Bern Convention which is not yet valid in Indonesia.

2. Revoke the copyright provisions that are not appropriate and replace them with those in accordance with the provisions of the TRIPs Agreement.

3. Determine the addition of creations stipulated in the TRIPs agreement called rights that are blessed with copyright.

The Bern Convention in 1886 basically contained the basic principle of provisions that set minimum standards of legal protection given to creators and specific provisions for WTO member countries. There are 3 (three) basic principles that must be applied by member countries in legislation in the field of copyright, namely [2]:

1. Principle of national treatment

Creations originating from one of the contracting participant countries, namely the creation of a citizen from a contracting country, or a work that was first published in one of the contracting countries must obtain the same copyright legal protection as obtained by the creation of a national citizen.

2. The principle of automatic protection

Providing legal protection must be given directly without having to fulfill any conditions.

3. The principle of independent of protection

The form of copyright law protection is provided without having to depend on the legal protection regulations of the originating country.

With reference to the enactment of the Berne convention provisions, the provisions of the declarative principle in the field of copyright are in accordance with the principle of copyright protection.

One of the most fundamental things on the declarative principle is the announcement of copyright registration. As is known, the relationship between the principle of declarative and fair to publish is at the announcement stage. Copyright protection will be given when the announcement is made by both the creator and the rights holders. According to UUHC what is meant by announcements is the reading, broadcasting, exhibition, a work using any tool whether electronic or non-electronic or doing it in any way so that a work can be read, heard or seen by others. The creator or the right holder has the economic right to make the announcement of the creation. This is an exclusive right for the creator or the right holder to give permission to others to listen, show, show the public through any means. The right to announce is also termed the Performing Right which is applied to the entertainment world, namely the rights obtained by 
the Creator in terms of carrying out his works. The main basis of consideration for the declarative principle of copyright is [3]:

1. Basic originality.

Forms of copyrighted works that have a basis of originality in the form of tangible evidence in the event of an IPR dispute and must be fulfilled.

2. The basis of the real form of copyright

Creative work is a real form and not just ideas or ideas

3. Basis is announced

Copyrighted works have been announced to both electronic and non-electronic media that can be read, heard and seen and can be enjoyed by the wider community.

4. Basic time period

Is a form of protection provided by the applicable statutory provisions.

\subsection{Declarative principle of copyright registration in era of disruption}

Disruption which means interference. Every quality new invention that creates a paradigmatic change will have the effect of overtaking old paradigm followers and actors who do not quickly respond or are too late in anticipating. Disruptive innovation is innovation that helps create new markets to disrupt or damage existing markets, and ultimately replace these earlier technologies. Disruption due to the development of information technology comes faster, massive and unpredictable.

The era of disruption is the result of rapidly developing information technology that affects all aspects of human life, one of which is in the field of copyright. Seeing this situation, even though the copyright adheres to the declarative principle, it still requires copyright registration. Registration of copyright is not an obligation to obtain copyright but is a willingness for the creator or right holder. This means that copyright both registered and unregistered still get the same protection by law.

Online forms of registration began to be developed by the Director General of Intellectual Property Rights. These efforts are taken to provide excellent service in the field of copyright to the community, thus a system that is transparent, accountable, fast, simple accurate, and economical is highly expected by stakeholders (stakeholders). The ease of registration through efiling system is expected to improve service with the application process carried out on-line, efficient and effective quickly so that it is not hampered by space and time wherever it can register as long as it is connected to the internet.

The development of intellectual property systems is a real need along with projections of economic, industrial development and anticipation of the impact of globalization. Experts consider globalization to be a phenomenon that arises due to the advancement of knowledge and technology, thus the intensity of globalization is triggered by the advancement of information technology and telecommunications. Strategies and technical and substantial forms in the field of intellectual property need to be developed in order to adapt to existing developments. Intellectual property is a strategic factor in determining competitiveness as well as a symbol of achievement in the era of globalization which is a mainstay in winning industry and trade rivalries [4].

Supported by the 2008 number 11 Law concerning Information and Electronic Transactions, hereinafter referred to as the ITE Law, in the framework of the ideal service in the field of intellectual property, the Director General of Intellectual Property Rights uses electronic applications in submitting copyright applications. The application is known as the KI E-Filing. The registration system that uses the application has not yet been applied to the entire field of intellectual property because it is still a process to connect with the symphony system (a system 
of payment for submission of intellectual property requests). At least the ITE Law regulates 2 (two) important matters, namely, first, the recognition of electronic transactions and electronic documents within the framework of legal agreements and evidentiary laws, so that the legal certainty of electronic transactions is guaranteed. Second, classified qualifying actions against legal violations related to misuse of information technology along with criminal sanctions including for carding, hacking and cracking. Online registration that is currently being implemented is the patent e-filing that began in 2012, copyright e-filing which has been started since October 2014, e-filing industrial design and e-filling brand extension which began in September 2015.

Online system services at the Director General of Intellectual Property Rights cannot be separated from the implementation of the functions of a public service institution that is easy, practical and transparent to the community. Through an online system, it makes it easy for copyright applicants to monitor the application process and payment process so as to create information transparency and prioritize services transparently. An online system, economically more efficient because it can reduce costs through simplification of procedures. The efficiency improvement is directly proportional to the legal certainty for the owner of the copyrighted work, with the principle of first to file using an online system, then the applicant can then not register the same name with the application that has already been requested, therefore time is very valuable. Even though the online system has been put into effect, the implementation is still not going well (technical constraints) so that it cannot be applied to all forms of intellectual property. Copyright e-filing is intended only for recording, there is no examination of the substance, therefore the process is fast. Registration of copyright does not mean endorsement of content created. The copyright will appear when first published in public [5].

Information technology-based e-filing and data services prove that there is a close link between the development of information technology and copyright. Copyright protection is used as a means to protect the results of human thought, whether those that do not involve technology or those that are in touch with technology, and vice versa, technology influences the way and management of intellectual property applications and data services. The steps taken by the Director General of IPR using technology and information in the process of registration and data service are appropriate in the context of free trade, which demands the higher quality of products produced [6].

\section{Conclusion}

Based on the discussion above the provisions of registration of creation according to Law Number 28 of 2014 concerning Copyright in Indonesia adhere to the declarative principle. The declarative principle in copyright protection is given automatically since the creation becomes real, independent of the originating state of the creator and has been announced for the first time by the creator or the right holder. The declarative principle in the disruption era is characterized by online system services at the Directorate General of Intellectual Property Rights, also known as e-filling. This concept uses the internet as a means of supporting copyright registration. Research needs to be done to implement the principle of declarative copyright registration to make it easier for creators or rights holders to get protection from the state. This is because in the era of disruption all will change quickly at any time without us knowing it. 


\section{REFERENCES}

[1] Candra Irawan, Politik Hukum Hak Kekayaan Intelektual, Kritik Terhadap WTO/TRPs Agreement dan Upaya Membangun Hukum Hak Kekayaan Intelektual Demi Kepentingan Nasional, Mandar Maju, Bandung, 2012.

[2] Cornish,W, R. Intellectual Property, Patent, Copyright, Trademarks and Alied Rights, (Sweet \& Maxwell, 2nd Edition, 1989.

[3] Eddy Darmain, Hukum Hak Cipta, Alumni, Bandung, 2014

[4] Friedman, W, Legal Theory, London:Steven \& Sons Limited, 1950

[5] Henry Sulistyo, Hak Kekayaan Intelektual : Konsepsi, Opini, dan Aktualisasi (Buku Pertama). Jakarta, 2014

[6] Kusumaatmadja, Mochtar, Hukum, Masyarakat dan Pembinaan Hukum Nasional, Bandung, Bina Cipta, Cet. Pertama, 1976.

[7] Mieke Yustia Ayu Ratna Sari, Pembangunan Kekayaan Intelektual Berbasis Teknologi Informasi di Era Global, Prosiding Seminar Nasional Multi Disiplin Ilmu \& Call For Papers Unisbank ke-2, 2016.

[8] Suyud Margono, Prinsip Deklaratif Pendaftaran Hak Cipta: Kontradiksi Kaedah Pendaftaran Ciptaan dengan Asas Kepemilikan Publikasi Pertama Kali, Jurnal Rechts Vinding, Volume 1 Nomor 2

\section{Regulations}

[1] Agreement on trade-Related Aspects of Intellectual Property Rights, Marrakesh, 15 April 1994

[2] Berne Convention for the Protection of Literary and Artistic Works, Paris Act of July 241971

[3] Undang-Undang Nomor 28 Tahun 2014 Tentang Hak Cipta 